\title{
Produksi Maggot Hermetia illucens Hasil Biokonversi Limbah Pertanian sebagai Sumber Pakan Ikan / Unggas Potensial di Desa Lawang Agung, Kabupaten Seluma
}

\author{
Bioconversion of Agricultural Waste Using Maggot Hermetia illucens \\ (Diptera: Stratiomyidae) as Potential Feedstuff Resources in the Lawang Agung \\ Village, Seluma Regency
}

Oleh :

Agustin Zarkani

Universitas Bengkulu

agustinzarkanil@unib.ac.id

Maya Angraini Fajar Utami

Universitas Bengkulu

maya.iklunib@gmail.com

Djamilah

Universitas Bengkulu

djamilah@unib.ac.id

\begin{abstract}
ABSTRAK
Usaha sampingan strategis masyarakat seperti ternak unggas dan ikan telah terbukti mampu menopang perekonomian masyarakat desa dan perkotaan, namun kondisi ini mengalami penurunan dan bahkan cendrung ditinggalkan karena terbatasnya sumber pakan alami serta mahalnya harga pakan dampak dari naiknya nilai tukar rupiah dan perubahan iklim yang ekstrim. Salah satu usaha mengatasi permasalah tersebut adalah dengan introduksi pemanfaatan potensi sumberdaya lokal yaitu biokonversi limbah pertanian milik masyarakat desa melalui program Pengabdian pada Masyarakat (PPM). Kegiatan PPM dilakukan dari bulan Juli-Agustus 2019 di Desa Lawang Agung, Kecamatan Air Periukan, Kabupaten Seluma yang merupakan desa binaan Jurusan Perlindungan Tanaman, Fakultas Pertanian, Universitas Bengkulu. Hasil kegiatan PPM ini telah mampu melatih para petani muda usia 18-45 tahun dalam memanfaatkan sampah loading ramp pabrik kelapa sawit dan limbah batang jagung untuk media budidaya maggot Hermetia. Meskipun paket teknologi PkM telah diketahui oleh $50 \%$ peserta sebelum program dimulai, namun tidak satupun peserta yang pernah mencobanya. Daya serap teknologi dan kemampuan praktek peserta sangatlah tinggi yaitu berurutan mencapai $93 \%$ dan $100 \%$. Ketertarikan peserta untuk menerapkan usaha mencapai $80 \%$. Masalah gender ditemukan dalam program penerapan iptek ini yaitu peserta wanita kurang tertarik untuk melanjutkan budidaya maggot Hermetia karena bentuknya yang tidak disukai.
\end{abstract}

Katakunci: Biokonversi, Hermetia, limbah pertanian, pengabdian masyarakat, pakan alami 


\begin{abstract}
Poultry and fish farming business have been able to sustain the economic rate in rural and urban communities. However, this economic activity has declined and tends to be abandoned due to lack of natural feed resources and high feed prices caused by climate change and inflation, respectively. To overcome the problem, an introduction of potential methods such as bioconversion of agricultural waste closed to rural communities through a community service program (CSP) is needed. The CSP activity was carried out during July-August 2019 in Lawang Agung Village, Air Periukan Subdistrict, Seluma District which is a fostered village of the Plant Protection Department, Faculty of Agriculture, Bengkulu University. The program results that both waste of loading ramp of palm oil factory and corn have a similar potential to be a biocoversion. About 20 farmers aged 18-45 years were trained in utilizing agricultural waste for cultivating BSF maggot. Although the technology package was known by $50 \%$ of participants before the program began, none of the participants had tried it. The absorption of technology and the practice ability of participants is very high, respectively $93 \%$ and $100 \%$. The participants' interest in implementing the business reaches $80 \%$. Gender issues were found in this science and technology application program that female participants were less interested in continuing BSF cultivation because of its maggot form.
\end{abstract}

Keywords: Agricultural waste, bioconversion, community service, feedstuff, Hermetia

\title{
PENDAHULUAN
}

Desa Lawang Agung, Kecamatan Air Periukan, Kabupaten Seluma, Propinsi Bengkulu adalah desa mandiri-teladan Provinsi Bengkulu tahun 2018. Desa induk yang terletak di sekitar pabrik pengolahan Crude Palm Oil (CPO) milik PT. Agriandalas ini dikenal juga sebagai desa percontohan tata kelola lingkungan dan administrasi pemerintahan desa terbaik pada dua tahun terakhir. Lokasi pusat desa dan kecamatan sebagai tempat pelaksanaan dengan Universitas Bengkulu sebagai perguruan tinggi pelaksana program pengabdian berjarak sekitar $35 \mathrm{~km}$ (peta lokasi terlampir). Masyarakat desa Lawang Agung merupakan masyarakat campuran antara masyarakat asli daerah dengan masyarakat transmigrasi asal Jawa. Sebagai Desa induk kecamatan dan sekaligus desa tertua, desa ini memiliki peran penting dalam inisiator bagi perkembangan desa-desa di sekitarnya.

Masyarakat desa Lawang Agung umumnya berprofesi sebagai buruh harian (10\%), petani palawija dan kelapa sawit (80\%), pedagang (5\%) serta lainnya (5\%). Meskipun berada di sentral kawasan pabrik CPO, perekonomian masyarakat desa belum begitu mapan. Rata-rata satu keluarga hanya memiliki satu hektar lahan dengan nilai ekonomis produksi lahan sekitar 2-3 juta/bulan (Data Kecamatan, 2018).

Selain mayoritas berprofesi sebagai petani, memelihara ternak unggas dan ikan adalah profesi sampingan strategis masyarakat desa yang cukup penting. Terbukti saat krisis moneter tahun 1998 dan anjloknya harga sawit pada pertengahan tahun 2009, sektor sampingan inilah yang dapat mempertahankan perekonomian masyarakat setempat. Kondisi yang sama juga terulang saat ini, dimana harga sawit yang belum begitu pulih sejak awal tahun 2018 lalu, profesi sampingan ini menjadi penyokong ekonomi desa. Akan tetapi meningkatnya harga pakan serta terbatasnya sumber pakan alami membuat masyarakat desa perlahan mengurangi aktifitas sampingan tersebut. Tercatat 
selama rentang tahun 2010-2018 terdapat sekitar 20\% masyarakat tidak lagi menekuni aktifitas sebagai peternak ayam dan pemelihara ikan karena alasan mahalnya pakan (laporan tahunan desa, 2018).

Melemahnya kondisi perekonomian masyarakat desa Lawang Agung dan desa-desa di sekitarnya saat ini akibat perubahan iklim yang ekstrim yang berdampak pada menurunnya produksi pertanian dan juga dampak mahalnya harga pakan unggas dan ikan telah menurunkan pendapatan utama dan sampingan masyarakat setempat. Kedepannya, melemahnya perekonomian ini akan berdampak juga pada penurunan kemampuan masyarakat dalam pemenuhan kebutuhan pangan, kesehatan, pendidikan, dan lainnya.

Adanya permasalahan utama masyarakat desa calon mitra Pengbadian Pada Masyarakat (PPM) di atas, maka dilakukan solusi kongrit melalui transfer pengetahuan dan keahlian tentang pemanfaatan potensi sumberdaya lokal seperti biokonversi limbah pertanian dan sampah loading ramp pabrik CPO yang banyak tersedia di sekitar Desa Lawang Agung sebagai pakan ikan/unggas alternatif. Teknologi biokoversi limbah pertanian menjadi media hidup maggot serangga lalat Black Soldier Fly (BSF) (Diptera: Stratiomyidae), Hermetia illucens ini belum dimanfaatkan para petani dan masyarakat padahal teknologi budidayanya sudah banyak dikembangkan oleh banyak para peneliti (Bondari \& Sheppard 1981; Hem et al. 2007; Zarkani \& Miswarti, 2012; Zarkani, 2013) termasuk peneliti dari Universitas Bengkulu (Zarkani, 2012).

\section{METODE PENGABDIAN}

Kegiatan pengabdian pada masyarakat (PPM) ini dilakukan dengan metode penyuluhan dan demo lapang (demplot) dengan rangkaian kegiatan sebagai berikut:

1. Menjalin kemitraan dengan pihak pabrik CPO PT. Agri Andalas sebagai mitra penunjang yang menyuplai sampah loading ramp untuk media hidup maggot $H$. illucens sebagai sumber protein utama pellet. Kemitraan diawali dengan mengirimkan surat permohonan penyediaan sampah sebagai bahan baku pelatihan.

2. Melakukan sosialisasi dan demo/pelatihan produksi massal maggot H. illucens kepada para masyarakat yang tergabung dalam kelompok-kelompok tani atau organisasi kepemudaan desa.

3. Melakukan sosialisasi dan demo/pelatihan produksi pakan pellet dan selanjutnya masyarakat mitra akan memproduksi dan membudidayakan sendiri maggot.

4. Pendampingan masyarakat dalam mempertahankan kualitas dan kesinambungan produksi.

5. Pendampingan kepada masyarakat mitra terhadap pengemasan dan pemasaran pakan pellet dalam pengantisipasian produksi yang melimpah guna dipasarkan keluar daerah atau lainnya. 
Kegiatan ini selanjutnya dievaluasi di awal dan akhir setiap satuan acara kegiatan sehingga memungkinkan untuk dilakukan perbaikan berikutnya. Beberapa kriteria keberhasilan pencapaian tujuan adalah :

1. Minimal $90 \%$ peserta memiliki antusias yang tinggi saat berlangsungnya kegiatan. Indikator ini dilihat dari intensitas pertanyaan yang diajukan peserta serta jumlah kehadiran peserta selama lima tahap pelatihan.

2. Minimal $90 \%$ peserta mampu menguasi teknik budidaya manggot. Kemampuan ini dinilai dari hasil pre dan post test di setiap sessi kegiatan.

3. Tertariknya peserta untuk menyebarkan dan menerapkan teknologi yang diberikan. Keberhasilan ini diukur dengan pernyataan ketertarikan peserta yang terekam pada angket dan quiser yang diberikan pada setiap akhir sesi pelatihan.

\section{HASIL DAN PEMBAHASAN}

Kegiatan pengabdiaan pada masyarakat (PPM) penerapan ilmu pengetahuan dan teknologi (Iptek) ini melibatkan 3 orang dosen, 2 orang mahasiswa dan 16 orang para petani yang sekaligus berprofesi sampingan sebagai peternak. Sebanyak 13 orang peserta berasal dari desa Lawang Agung sedangkan 3 orang peserta lainnya berasal dari desa tetangganya yaitu Keban Agung. Cukup antusiasnya para peserta untuk mengikuti program pengabdian ini terlihat dari banyaknya permintaan tambahan peserta dari masyarakat yang belum ikut untuk dapat dilibatkan pada kegiatan berikutnya. Para peserta umumnya adalah para petani muda dengan kisaran umur 18-45 tahun.

Kegiatan PPM tahap pertama secara formal telah dilaksanakan pada hari Selasa tanggal 20 Agustus 2019. Meskipun dua minggu sebelumnya telah dilakukan kunjungan persiapan yang meliputi rapat penentuan calon peserta serta penyiapan bahan-bahan yang akan digunakan. Kegiatan ini dikonsentrasikan di areal sentral rumah kompos milik Desa Lawang Agung. Acara PPM dibuka secara resmi oleh pejabat Kepala Desa Lawang Agung sedangkan dari pihak Universitas Bengkulu diwaliki oleh perwakilan Jurusan Perlindungan Tanaman (Gambar 1.a). 




Gambar 1. Kegiatan PPM tahap pertama. a) Para peserta PPM dan tim dosen pelaksana PPM, b-c) Penyampaian materi kegiatan, d) Memberikan contoh tentang paket penerapan Iptek yang akan dilakukan.

Pada awal kegiatan, peserta diberikan pre-test dalam bentuk kuisioner untuk mengukur kemampuan pemahamannya dan selanjutnya peserta diajak untuk memahami paket teknologi yang akan diterapkan. Kemudian para peserta dibekali dengan teori tentang maggot $H$. illucens serta peluang usahanya bila dikembangkan di Desa Lawang Agung (Gambar 1.b-d). Dari hasil kuisioner pertama, diketahui bahwa sekitar 50\% peserta telah mengetahui paket teknologi yang akan diberikan, namun tidak ada satupun di antara mereka yang pernah menerapkannya. Pengetahuan tentang paket teknologi ini pernah didapatkan oleh sebagian besar para peserta dari kegiatan sosialisasi Program Studi Proteksi Tanaman yang pernah disampaikan oleh para dosen Jurusan Perlindungan Tanaman pada awal tahun 2019 lalu.

Hasil evaluasi awal dan akhir kegiatan mendapatkan nilai daya serap teknologi dan kemampuan praktek para peserta sangatlah tinggi yaitu berurutan mencapai 93\% dan 100\%. Sedangkan ketertarikan peserta untuk mengembangkan usaha maggot mencapai $80 \%$ (Tabel 1). Dalam penerapan hasil akhir PPM ini ditemukan kendala dalam permasalahan gender yaitu para peserta wanita kurang tertarik untuk melanjutkan budidaya maggot $H$. illucens karena bentuknya yang tidak disukai karena mengelikan. Namun ketertarikan akan materi iptek yang disampaikan tidak menunjukan adanya bias gender.

Tabel 1. Tingkat keterampilan awal program pengabdian pada masyarakat

\begin{tabular}{lcc}
\hline \multicolumn{1}{c}{ Parameter } & $\begin{array}{c}\text { Sebelum } \\
\text { Kegiatan }\end{array}$ & $\begin{array}{c}\text { Setelah } \\
\text { Kegiatan }\end{array}$ \\
\hline Mengerti atau tahu tentang lalat BSF H. illucens & $50 \%$ & $100 \%$ \\
\hline $\begin{array}{l}\text { Pernah mencoba / keterlibatan praktek budidaya } \\
\text { lalat BSF H. illucens }\end{array}$ & $0 \%$ & $100 \%$ \\
\hline $\begin{array}{l}\text { Ketertarikan untuk menggunakan bahan-bahan } \\
\text { alam sebagai bahan biokonversi }\end{array}$ & $75 \%$ & $100 \%$ \\
\hline $\begin{array}{l}\text { Mengetahui tentang teknik produksi maggot } \\
\text { H. illucens secara lengkap (daya serap materi) }\end{array}$ & $0 \%$ & $94 \%$ \\
\hline $\begin{array}{l}\text { Keinginan untuk mengembangkan maggot } \\
\text { H. illucens }\end{array}$ & $31 \%$ & $88 \%$ \\
\hline
\end{tabular}


Di akhir kegiatan tahap pertama ini, semua peserta telah mengetahui tentang cara budidaya lalat BSF dan telah diproduksi pakan persiapan maggot sebanyak $100 \mathrm{~kg}$. Dari jumlah pakan tersebut diharapkan pada kegiatan tahap kedua nantinya dapat memproduksi sekitar 30-40 kg maggot basah yang siap olah.

Pada kegiatan tahap berikutnya, tim PPM mempraktekkan tentang teknik produksi maggot dari bahan fermentasi limbah pertanian yang meliputi: 1). Teknik pemancingan dan pemeliharaan serangga dewasa; 2). Teknik pemanenan telur; 3). Teknik pembesaran maggot; 4) Teknik pemanenan maggot; 5) Pembuatan pelet dan non-pelet; 6) Pengemasan. Kesemua proses produksi ini dilakukan sesuai tahapan rencana dan target capaian (Gambar 2.a-d).

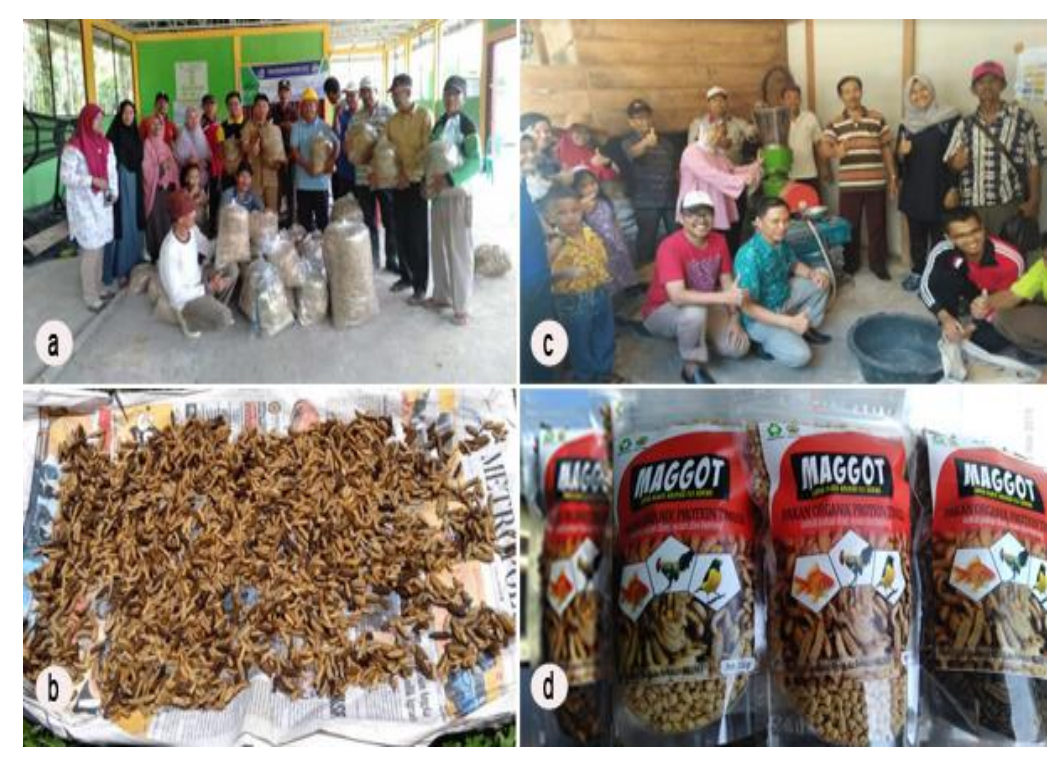

Gambar 2. Produksi maggot Hermetia illucens. a) Pembuatan media hidup maggot dari sampah loading ramp kelapa sawit dan limbah batang jagung, b) Panen maggot yang dihasilkan, c) Proses pembuatan pellet ikan berbahan maggot, d) Bentuk kemasan maggot kering dan pellet.

Hasil evaluasi akhir dari kegiatan ini disajikan pada Tabel 2 yaitu semua para peserta telah mengerti dan puas terhadap program PPM yang telah dilakukan. Meskipun demikian, diketahui bahwa tidak semua para peserta bersemangat untuk mengajak orang lain di sekitar tempat tinggalnya dalam melakukan kegiatan usaha bersama (nilai 95). Hal ini disebabkan oleh beberapa faktor yang diantaranya adalah tingkat kepraktisan teknologi budidaya maggot yang disampaikan masih dirasakan kurang oleh beberapa peserta (nilai 88). Faktor lainnya adalah munculnya bias gender dimana para peserta dari kaum wanita cendrung kurang tertarik untuk melanjutkan kegiatan disebabkan oleh bentuk maggot seperti belatung yang tidak disukai atau menggelikan. 
Dharma Raflesia : Jurnal Ilmiah Pengembangan dan Penerapan IPTEKS

18 (1) 2020

Tabel 2. Tingkat keterampilan akhir para peserta pengabdian pada masyarakat

\begin{tabular}{lc}
\hline \multicolumn{1}{c}{ Parameter } & Nilai (1-100) \\
\hline $\begin{array}{l}\text { Mengerti atau tahu tentang teknik memanen maggot } \\
\text { BSF Hermetia illucens }\end{array}$ & 100 \\
\hline $\begin{array}{l}\text { Mengerti atau tahu tentang membuat pelet berbahan } \\
\text { maggot Hermetia illucens }\end{array}$ & 100 \\
\hline $\begin{array}{l}\text { Keinginan untuk mengajak orang lain dalam } \\
\text { berusaha bersama }\end{array}$ & 95 \\
\hline Kepraktisan teknologi yang disampaikan & 88 \\
\hline Kepuasan terhadap program yang dilakukan & 100 \\
\hline
\end{tabular}

KESIMPULAN DAN SARAN

\section{Kesimpulan}

Kegiatan introduksi teknik budidaya maggot Hermetia illucens hasil dari biokonversi limbah pertanian dan sampah loading ramp pabrik CPO kelapa sawit dan limbah batang jagung sebagai sumber pakan ikan dan unggas ini telah memberikan keahlian kepada 16 peserta target program penerapan iptek dengan tingkat capaian keberhasilan penguasaan teknologi mencapai $100 \%$. Tingkat ketertarikan peserta untuk mengajak orang lain di sekitar tempat tinggalnya dalam melakukan kegiatan usaha bersama cukup tinggi yaitu 95\% dengan tingkat kepraktisan teknologi sekitar 88 poin. Meskipun demikian, faktor gender perlu diperhatikan dalam PPM ini dimana para peserta dari kaum wanita cendrung kurang tertarik untuk melanjutkan kegiatan disebabkan oleh bentuk fisik maggot hidup yang tidak disukai. Adanya partispasi dan antusias masyarakat desa sasaran PPM yang tinggi ditunjukan dengan adanya permintaan penambahan jumlah peserta serta permintaan tema pelatihan lanjutan/ikutan.

\section{Saran}

Kegiatan ini membutuhkan partisipasi lebih banyak lagi dari pihak Pemda Seluma dan swasta agar kegiatan penerapan iptek dapat dijadikan sebagai peluang munculnya wirausaha baru berbasis limbah pertanian. Kaum wanita yang kurang tertarik terhadap bentuk fisik maggot hidup dapat tetap dilibatkan yaitu pada proses pembuatan pellet. 


\section{DAFTAR PUSTAKA}

Bondari, K.., Sheppard D.C., 1981, Soldier Fly Larvae as Feed in Commercial Fish Production, Aquaculture, 24,103-109. http://dx.doi.org/10.1016/0044-8486.

Hem, S., Rini, M., Chumaidi, Maskur, A., Hadadi, Supriyadi, Ediwarman, Larue, M., Pouyaud, L., 2007, Volarization of Palm Kernel Meal (PKM), A By-Product from Palm Oil Agro Industry, Via Bioconversion: A Natural Process of Particular Interest for The Development of Aquaculture in Indonesia, International Conference on oil palm and environment, 15-16 November 2007, Bali: Indonesia.

Zarkani, A. (2010). Peluang budi daya larva Hermetia illucens berbasis aneka limbah sawit. In Poster Session Seminar Nasional Biomass Energi Kelapa Sawit (Bengkulu, 20 Desember 2010).

Zarkani, A., 2012, Black Soldier Fly Hermetia illucens (Diptera: Stratiomyidae): From Waste to Wealth and Prosperity, Proceeding $3^{\text {rd }}$ International Seminar Regional Network on Poverty Eradication, 15-17 October, Bengkulu.

Zarkani, A., 2013, Teknik Budidaya Mangot Hermetia illucens (Diptera: Stratiomyidae) sebagai Sumber Protein Pakan Ikan Alternatif, Bengkulu-Indonesia: UNIB Press.

Zarkani, A., \& Miswarti, M. (2015). Teknik budi daya larva Hermetia illucens (Linnaeus)(Diptera: Stratiomyidae) sebagai sumber protein pakan ternak melalui biokonversi limbah loading ramp dari pabrik CPO. Jurnal Entomologi Indonesia, 9(2), 49. 